\title{
Estimate of Uniaxial Compressive Strength of Hydrothermally Altered Soft Rocks Based on Strength Index Tests
}

\author{
Masanori Kohno', Hiroyuki Maeda ${ }^{2}$ \\ ${ }^{1}$ Graduate School of Engineering, Tottori University, Tottori, Japan \\ ${ }^{2}$ Sapporo Technology Professional Training College, Sapporo, Japan \\ Email:kohnom@tottori-u.ac.jp
}

How to cite this paper: Kohno, M. and Maeda, H. (2018) Estimate of Uniaxial Compressive Strength of Hydrothermally Altered Soft Rocks Based on Strength Index Tests. Geomaterials, 8, 15-25. https://doi.org/10.4236/gm.2018.82002

Received: April 12, 2018

Accepted: April 27, 2018

Published: April 30, 2018

Copyright (c) 2018 by authors and Scientific Research Publishing Inc. This work is licensed under the Creative Commons Attribution International License (CC BY 4.0).

http://creativecommons.org/licenses/by/4.0/

\section{c) (i) Open Access}

\begin{abstract}
The purpose of this study was to clarify the relationships between results of index tests and uniaxial compressive strength (UCS) in hydrothermally altered soft rocks of the Upper Miocene, which are typical of the soft rock found in northeastern Hokkaido, Japan. Index tests were performed using point load testing machine and needle penetrometer with irregular lump specimens under forced-dry, forced-wet, and natural-moist states. The relationships between irregular lump point load strength (IPLS) index and UCS, and needle penetration (NP) index and UCS were "UCS = approximately 19 IPLS index"

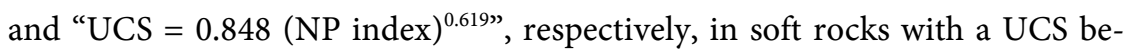
low $25 \mathrm{MPa}$. These relationships could be applied to on-site tests of rocks with natural moisture content. The UCS could be calculated from IPLS and NP tests on soft rocks only when UCS was below $25 \mathrm{MPa}$, using the equations obtained as a result of this study.
\end{abstract}

\section{Keywords}

Uniaxial Compressive Strength (UCS), Irregular Lump Point Load Strength (IPLS) Index, Needle Penetration (NP) Index, Empirical Equation, Hydrothermally Altered Rocks

\section{Introduction}

The strength of rocks is generally evaluated based on uniaxial compressive strength (UCS). However, rock core pieces for UCS tests cannot always be obtained from outcrops of faulted, jointed, or heavily crushed rock masses. In these cases, the point load strength (PLS) or needle penetration (NP) test is a conve- 
nient and effective alternative to the UCS test because it can be done promptly using onsite testing equipment with various shaped small rock specimens taken from outcrops or floats. Provided that UCS can be estimated from a PLS or NP value, PLS and NP tests are more convenient and cheaper.

Many researchers have already studied the relationship between the PLS index and UCS. The representative relationships between the PLS index and UCS are shown in Table 1. In these relationships, the maximum values of UCS ranged from 150 to $350 \mathrm{MPa}$ (Table 1). Furthermore, the number of points on soft rocks (UCS $=25 \mathrm{MPa}$ or less) was less than the number of points on hard rocks (UCS $=25 \mathrm{MPa}$ or more). Therefore, it could not be considered that these studies have clarified the relationship between the PLS index and UCS of soft rocks. Relationship between the PLS index and UCS of soft rocks was determined by Tsiambaos and Sabatakakis [12] (2004; UCS = 13 PLS, Maximum value of UCS is $50 \mathrm{MPa}$ ), Basu and Aydin [13] (2006; UCS = 18 PLS, Maximum value of UCS is $200 \mathrm{MPa}$ ), Agustawijaya [14] (2007; UCS = 13.4 PLS, Maximum value of UCS is $12 \mathrm{MPa}$ ), and Kohno and Maeda [15] (2012; UCS = 16.4 PLS, Maximum value of UCS is $25 \mathrm{MPa}$ ). Recently, Wong et al. (2017) [16] have studied the UCS and PLS index of volcanic irregular lumps.

Smaller samples are difficult to obtain even for PLS tests. In this case, the NP test is convenient and effective. Recently, relationship between the NP index and UCS of rocks was determined by Park et al. (2011) [17], Ngan-Tillard et al. (2011, 2012) [18] [19], Ulusay and Erguler (2012) [20], Azadan and Ahangari (2014) [21], Ulusay et al. (2014) [22], and Kahraman et al. (2017) [23]. The most popular UCS-NP equation was proposed by Okada et al. (1985) [24]. However, this equation mainly used cement material specimens, and there are very few reports about the relationship between the NP index and UCS of soft rocks.

The purpose of this study was to investigate the relationship between the PLS index and UCS of hydrothermally altered soft rocks, which are typically found in

Table 1. Typical examples of equations correlating uniaxial compressive strength to the point load strength.

\begin{tabular}{|c|c|c|}
\hline References & Equations & $\begin{array}{l}\text { Maximum value } \\
\text { of UCS (MPa) }\end{array}$ \\
\hline D’Andrea et al. (1964) [1] & $\mathrm{UCS}=15.3 \mathrm{PLS}+16.3$ & 350 \\
\hline Broch and Franklin (1972) [2] & $\mathrm{UCS}=23.7$ PLS & 250 \\
\hline Bieniawski (1974; 1975) [3] [4] & $\mathrm{UCS}=23 \mathrm{PLS}$ & 350 \\
\hline Brook $(1977 ; 1980)[5][6]$ & $\mathrm{UCS}=12.5$ PLS & 300 \\
\hline Hassani et al. (1980) [7] & UCS $=29$ PLS & 200 \\
\hline $\begin{array}{c}\text { ISRM Commission (1985) [8]; } \\
\text { Brook (1985) [9] }\end{array}$ & $\mathrm{UCS}=20 \cdots 25$ PLS & 250 \\
\hline Hikita and Kikuchi (1988) [10] & $\mathrm{UCS}=12.3 \cdots 15.0$ PLS & 200 \\
\hline Kahraman (2001) [11] & $\mathrm{UCS}=23.62 \mathrm{PLS}-2.69$ & 150 \\
\hline Kahraman (2001) [11] & $\mathrm{UCS}=8.41 \mathrm{PLS}+9.51$ & 150 \\
\hline
\end{tabular}


northeastern Hokkaido, Japan (Figure 1), using irregular lump PLS (IPLS) test specimens. In addition, we obtained the relationship between the NP index and UCS. It is expected that the results can provide a practical method that will be useful for evaluation of landslide hazards, for landslide hazard mapping, rock classification, and other applications.

\section{Rock Samples}

Rock samples, which were collected primarily from the earth's surface in ancient hydrothermal fields in northeastern Hokkaido, Japan, were hydrothermally altered volcaniclastic rocks, including fine tuff, medium tuff, pumice tuff, lapilli tuff, welded tuff, dacite, tuffaceous mudstone, tuffaceous sandstone, and tuffaceous conglomerate. The modes of occurrence of these hydrothermally altered rocks were examined in the field, and the hydrothermal alteration minerals in the rocks were identified primarily by X-ray powder diffraction (XRD) tests.

\section{Methods and Equipment}

\subsection{Irregular Lump Point Load Strength Test}

The IPLS test was conducted in accordance with ISRM Commission (1985) [8]. In the IPLS tests, the specimens were loaded to failure by application of a concentrated load through a pair of spherically truncated, conical platens. The testing machine consisted of conical loading platens, a loading frame, dial gauge, manual control handle, load cell, and load measuring system (Figure 2). The loading speed was set so that each specimen failed within $10-60 \mathrm{~s}$. This was achieved using a manual control handle by loading each specimen continuously at a constant (as much as possible) loading speed up to approximately $100 \mathrm{~N} / \mathrm{s}$ of load increase. The size-corrected IPLS index of a rock specimen was defined as the value of PLS that would have been measured by a diametral PLS test with diameter $D=50 \mathrm{~mm}\left(D_{\mathrm{e}}^{2}=2500 \mathrm{~mm}^{2}\right.$, where $D_{\mathrm{e}}$ is the equivalent core diameter). The IPLS index can be represented by the formula:

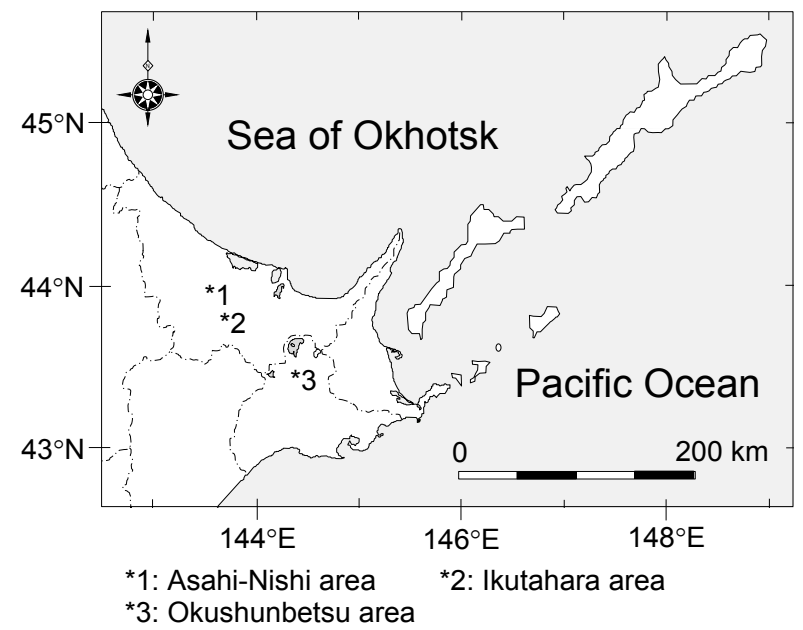

Figure 1. Location of the sampling sites in northeastern Hokkaido, Japan. 

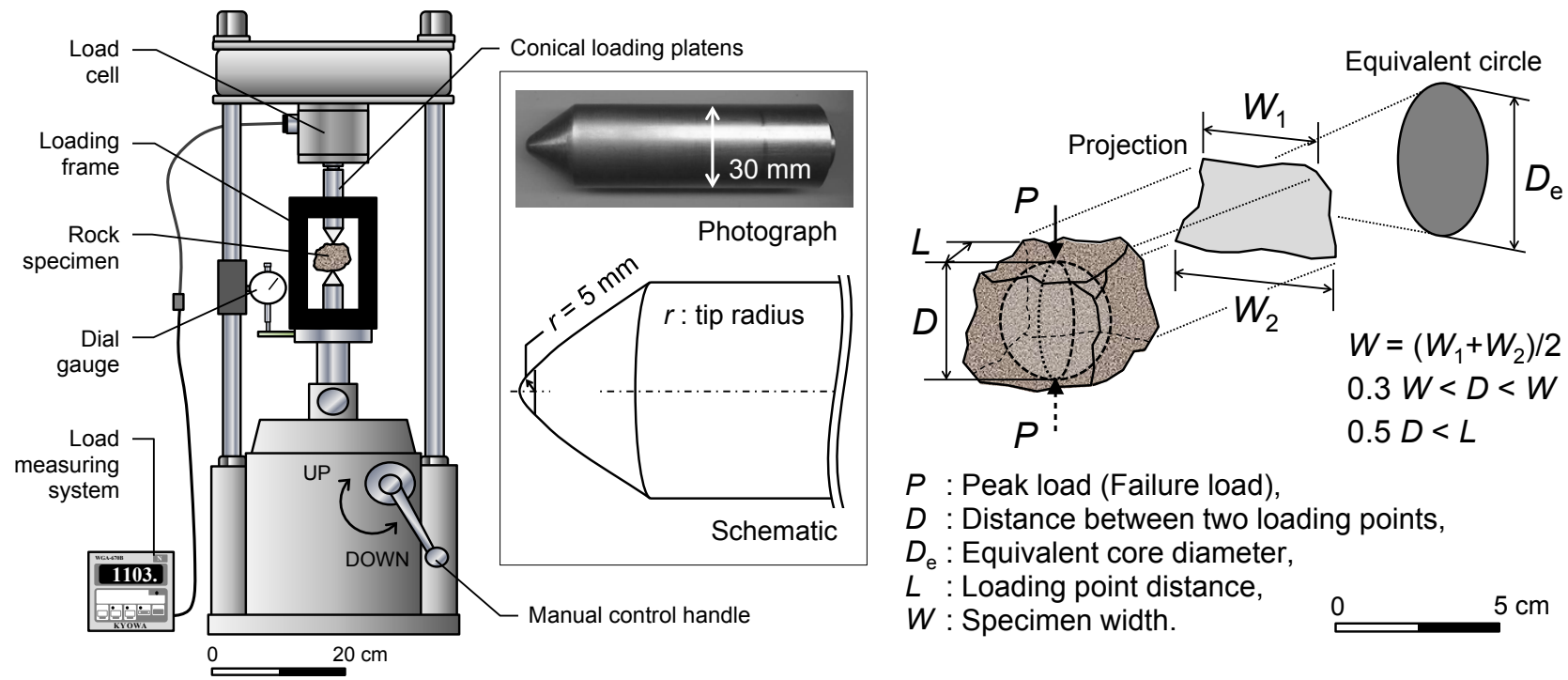

Figure 2. Point load strength testing machine, shape of rock specimen, load configuration, and conditional expression for irregular lump point load strength test.

$$
I_{\mathrm{s}(50)}=F \frac{P}{D_{\mathrm{e}}^{2}}
$$

where $F$ is the size correction factor, $P$ is the peak load (failure load), and $D_{\mathrm{e}}$ is the equivalent core diameter. $D_{\mathrm{e}}$ is the diameter of a circle with an area equal to the minimum area of the cross sections containing the two loading points, and can be represented by the formula:

$$
D_{\mathrm{e}}^{2}=\frac{4 W D^{\prime}}{\pi}
$$

where $D_{\mathrm{e}}$ is the equivalent core diameter, $W$ is the specimen width, and $D^{\prime}$ is the distance between the two loading platens at the time of failure. The ISRM Commission (1985) [8] stipulated that if significant penetration of the conical platens occurs during the test, such as when testing soft rocks, the value of $D^{\prime}$ should be the final value of the distance between the two loading platens. Therefore, in this study, the PLS was calculated using the distance between the two loading platens at the time of failure:

$$
D^{\prime}=D-\alpha
$$

where $D^{\prime}$ is the distance between the two loading platens at the time of failure, $D$ is the distance between the two loading platens, and is the penetration distance of the conical platens. The distance between the two loading platens and the penetration distance of the conical platens were measured using slide calipers and a dial gauge (analog type), respectively. $F$ can be represented by the formula:

$$
F=\left(\frac{D_{\mathrm{e}}}{50}\right)^{0.45}
$$

where $F$ is the size correction factor, and $D_{\mathrm{e}}$ is the equivalent core diameter. 
In this study, irregular lump specimens were used for the IPLS tests (Figure 2). The IPLS test specimen sizes satisfied the conditional expression of $0.3 W<D$ $<W$ and $0.5 D<L$ (ISRM Commission (1985) [8]; Figure 2).

\subsection{Needle Penetration Test}

The NP test was conducted in accordance to the methods proposed by Okada et al. (1985) [24] The needle penetrometer (Figure 3) consisted of the penetration needle, load indication ring, penetration and load scales, chuck, spindle, and penetration indication cap. The NP index can be represented by the formula:

$$
\text { NP index }=\frac{P}{a}
$$

where $P$ is the penetration load, and a is the penetration depth.

\subsection{Specimen Moisture Content and Number of Specimens}

The IPLS, NP, and UCS tests in this study were performed using a laboratory testing machine with specimens in forced-dry, forced-wet, and natural-moist states. The forced-dry and forced-wet states included absolutely dry and fully water-saturated specimens, respectively. The specimens were dried in an electric oven at a temperature below $60^{\circ} \mathrm{C}$ for 4 days or more to achieve a constant mass and were saturated with water for 15 days or more to achieve a constant mass, respectively (Kohno et al. (2010) [25]).

A total of 9 different rock types were sampled, and the total number of rock specimens tested was 2413 for the IPLS test, 180 for the NP test, and 262 for the UCS test (Table 2). The number of specimens in Table 2 does not include invalid test specimens.

\section{Results and Considerations}

Data points in the Figures 4(a)-(d) and Figure 5 is the average value of specimens, and numbers of the points is same numbers of sampling sites.

\subsection{Relationship between IPLS Index and Uniaxial Compressive Strength}

The relationships between the IPLS index and UCS in soft rocks with a UCS below $25 \mathrm{MPa}$ are shown in Figure 4. Such samples that do not satisfy the number

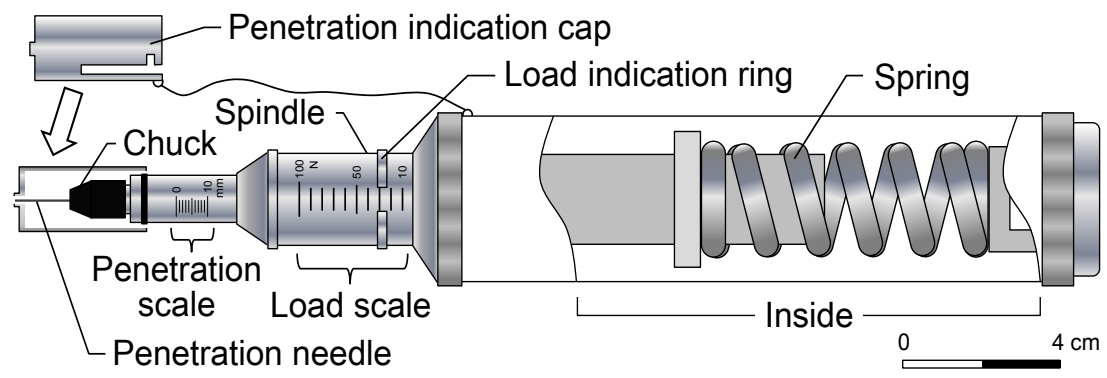

Figure 3. Needle penetrometer. 
Table 2. Numbers of specimens and sampling sites.

\begin{tabular}{|c|c|c|c|}
\hline \multirow{2}{*}{ Rock type } & \multicolumn{3}{|c|}{ Irregular lump point load strength test } \\
\hline & Forced-dry state & Forced-wet state & Natural-moist state \\
\hline $\mathrm{fTf}$ & $302(12)$ & $426(19)$ & $401(10)$ \\
\hline $\mathrm{m} \mathrm{Tf}$ & $25(1)$ & $22(1)$ & - \\
\hline $\mathrm{pm} \mathrm{Tf}$ & $195(6)$ & $129(6)$ & $81(2)$ \\
\hline lap Tf & $28(1)$ & $102(3)$ & $66(2)$ \\
\hline weld $\mathrm{Tf}$ & $76(3)$ & $66(3)$ & $50(1)$ \\
\hline $\mathrm{tfMs}$ & - & $15(1)$ & $46(1)$ \\
\hline tfSs & $117(3)$ & $96(3)$ & $100(2)$ \\
\hline $\mathrm{tfCg}$ & $10(1)$ & $12(2)$ & - \\
\hline $\mathrm{Dac}$ & $23(1)$ & $25(1)$ & - \\
\hline \multirow{2}{*}{ Rock type } & \multicolumn{3}{|c|}{ Needle penetration test } \\
\hline & Forced-dry state & Forced-wet state & Natural-moist state \\
\hline $\mathrm{fTf}$ & - & - & $100(10)$ \\
\hline $\mathrm{m} \mathrm{Tf}$ & - & - & - \\
\hline $\mathrm{pm} \mathrm{Tf}$ & - & - & $20(2)$ \\
\hline lap Tf & - & - & $20(2)$ \\
\hline weld Tf & - & - & $10(1)$ \\
\hline tfMs & - & - & $10(1)$ \\
\hline tfSs & - & - & $20(2)$ \\
\hline $\mathrm{tf} \mathrm{Cg}$ & - & - & - \\
\hline $\mathrm{Dac}$ & - & - & - \\
\hline \multirow{2}{*}{ Rock type } & \multicolumn{3}{|c|}{ Uniaxial compressive strength test } \\
\hline & Forced-dry state & Forced-wet state & Natural-moist state \\
\hline $\mathrm{fTf}$ & $35(12)$ & $63(19)$ & - \\
\hline $\mathrm{m}$ Tf & $1(1)$ & $1(1)$ & - \\
\hline $\mathrm{pm} \mathrm{Tf}$ & $34(6)$ & $32(6)$ & - \\
\hline lap Tf & $1(1)$ & $10(3)$ & - \\
\hline weld $\mathrm{Tf}$ & $16(3)$ & $16(3)$ & - \\
\hline tfMs & - & $3(1)$ & - \\
\hline tfSs & $19(3)$ & $17(3)$ & - \\
\hline tf $\mathrm{Cg}$ & $2(1)$ & $2(2)$ & - \\
\hline $\mathrm{Dac}$ & $5(1)$ & $5(1)$ & - \\
\hline
\end{tabular}

fTf: Fine tuff, m Tf: Medium tuff, pm Tf: Pumice tuff, lap Tf: Lapilli tuff, weld Tf: Welded tuff, tfMs: Tuffaceous mudstone, tfSs: Tuffaceous sandstone, tf Cg: Tuffaceous conglomerate, Dac: Dacite. ( ): Numbers of sampling sites. 


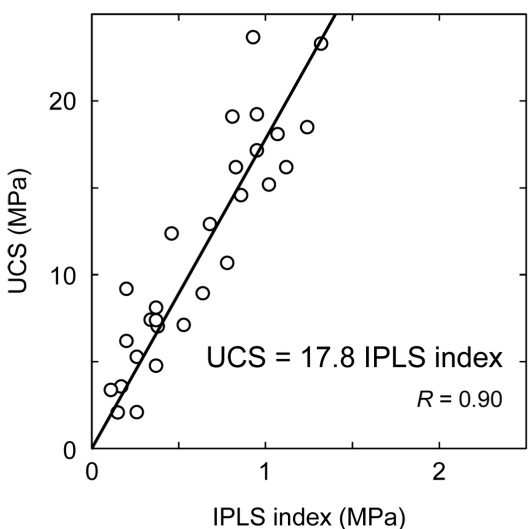

(a)

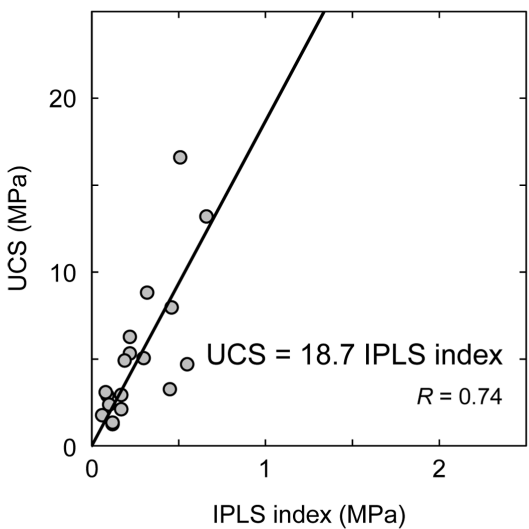

(d)

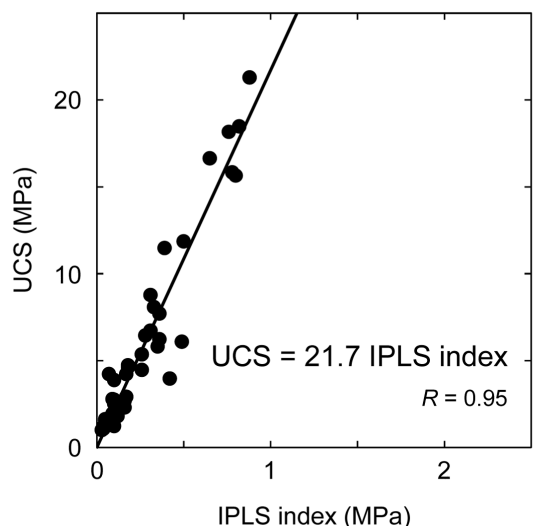

(b)

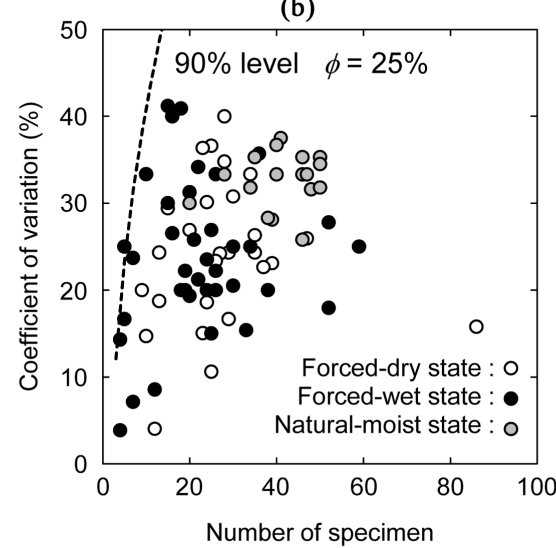

(e)

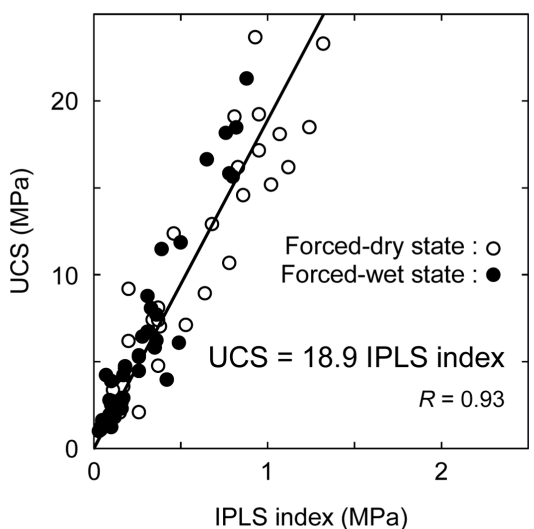

(c)

Figure 4. Relationship between irregular lump point load strength index and uniaxial compressive strength in the forced-dry state (a), forced-wet state (b), forced-dry and forced-wet states (c), natural-moist state (d), and relationship between number of irregular lump point load strength test specimens and coefficients of variation (e).

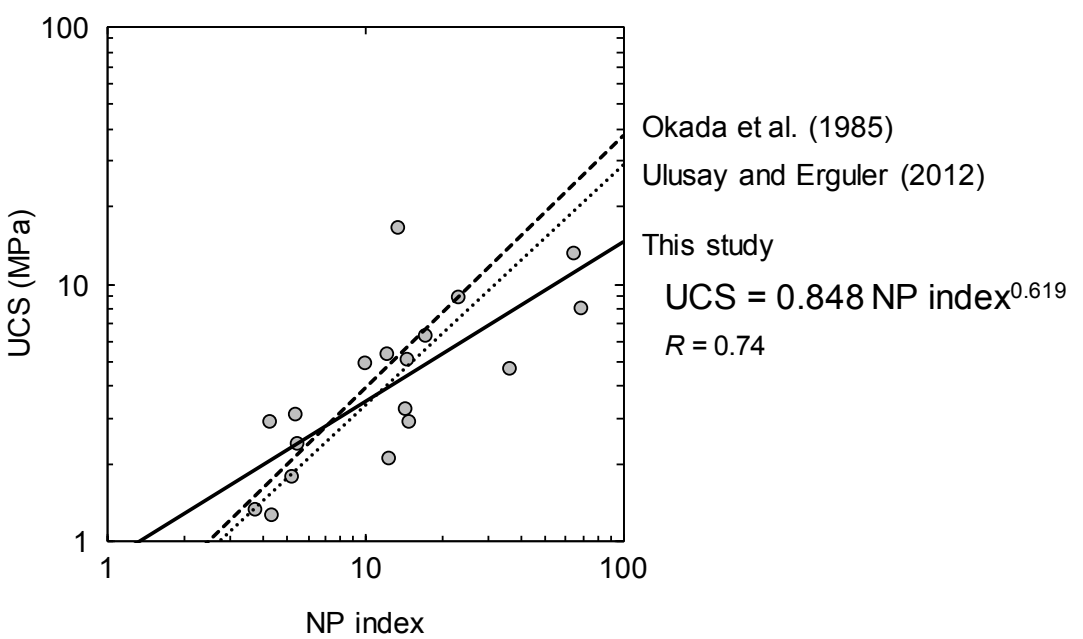

Figure 5. Relationship between needle penetration index and uniaxial compressive strength in the natural-moist state.

of specimens required for the coefficient of variation or those that have only one specimen were eliminated in IPLS and UCS tests, respectively; they were not included in the analysis. The correlations between the IPLS index and UCS in the 
forced-dry and forced-wet states were linear. The line drawn through the data points is the best fit, determined by the method of least squares regression. The equations and correlation coefficients for the forced-dry state were

UCS $=17.8 \times($ IPLS index), and $R=0.90$ (Figure 4(a)), respectively.

And those for the forced-wet state were

$\mathrm{UCS}=21.7 \times($ IPLS index), and $R=0.95$ (Figure 4(b)), respectively.

Here, $R$ is the correlation coefficient. The correlation coefficients for the forced-dry and forced-wet states were 0.90 and 0.95 , respectively, indicating a strong correlation. We attempted to combine the forced-dry and forced-wet states. The equation and correlation coefficient for the line were

UCS $=18.9 \times($ PLS index), and $R=0.93$ (Figure 4(c)), respectively.

Where $R$ is the correlation coefficient. The scatter in the data points was lesser at low strengths, and slightly higher at higher strengths (Figure $4(c)$ ). The relationship was established by combining those for the forced-dry and forced-wet states, and a strong correlation between them was observed as well. In soft rocks, the relationships between the IPLS index and UCS in the "forced-dry and forced-wet states (Figure 4(c))" and "natural-moist state (Figure 4(d))" were similar. Therefore, it can be concluded that it is also possible to apply the relationship to onsite tests of soft rocks in the natural-moist state, which is intermediate between the forced-dry and forced-wet states. The UCS under natural-moist state in this study was estimated based on water content of specimen.

\subsection{Relationship between NP Index and UCS}

The relationships between the NP index and UCS in soft rocks with a UCS below $25 \mathrm{MPa}$ are shown in Figure 5. The equation and correlation coefficients for the natural-moist state are

$\mathrm{UCS}=0.848 \times(\mathrm{NP} \text { index })^{0.619}$, and $R=0.74$ (Figure 5), respectively,

Where $R$ is the correlation coefficient. On comparing this equation to that proposed by Okada et al. $(1985$ [24]; $\log \mathrm{UCS}=0.978 \log (\mathrm{NP}$ index $)+1.599)$ and Ulusay and Erguler (2012 [20]; UCS $=0.4(\mathrm{NP} \text { index })^{0.929}$ ), there were differences observed in slope of the graph. One of the reasons why the equation in this study and that proposed by Okada et al. (1985) [24] and Ulusay and Erguler (2012) [20] differed was that the rock sample was a hydrothermally altered soft rock with a UCS below $25 \mathrm{MPa}$. Therefore, we need to choose either the equation proposed in this study (soft rocks) or that proposed by Okada et al. (1985) [24] and Ulusay and Erguler (2012) [20] (hard rocks). Thereby, we can obtain a more accurate value of UCS.

\subsection{Variation in the Tests}

The discrepancies in the IPLS and UCS tests were calculated using a coefficient of variation:

$$
C_{\mathrm{v}}=\frac{S}{x} \times 100(\%)
$$


where $C_{\mathrm{v}}$ is the coefficient of variation, $S$ is the standard deviation, and $x$ is the average of the IPLS (or UCS) test results. The coefficient of variation can be used to determine the number of specimens required for IPLS testing. The number of specimens required to obtain results within $\phi=25 \%$ of the average value over a one-sided confidence interval at a $90 \%$ level of confidence was 5,7 , and 10 for a $C_{\mathrm{v}}$ of $20 \%, 30 \%$, and $40 \%$, respectively (dashed line in Figure $4(\mathrm{e})$ ). The relationships between the number of IPLS test specimens and the coefficient of variation are shown in Figure 4(e). A sufficient number of specimens were used for most of the IPLS tests. The coefficient of variation for most UCS specimens was less than $25 \%$, ensuring that precise measurements were obtained for these tests. Therefore, the IPLS and UCS testing methods established in this study were highly precise. On the other hand, the coefficient of variation for most NP specimens was less than $20 \%$.

\section{Conclusions}

The following is a summary of our findings related to the UCS estimates of hydrothermally altered soft rocks from northeastern Hokkaido, Japan, based on our IPLS test and NP test results.

1) The relationships between the IPLS index and UCS and the NP index and UCS were "UCS $=$ approximately $19 \times($ IPLS index)" and "UCS $=0.848 \times($ NP index $)^{0.619}$ ", respectively in soft rocks with UCS below $25 \mathrm{MPa}$.

2) In soft rocks, the relationships between the IPLS index and UCS in the "forced-dry and forced-wet states" and "natural-moist state" were similar. Therefore, it can be concluded that it is also possible to apply the relationship to onsite tests of soft rocks in the natural-moist state, which is intermediate between the forced-dry and forced-wet states.

3) We need to choose either the equation proposed in this study (soft rocks) or that proposed Okada et al. (1985) [24] and Ulusay and Erguler (2012) [20] (hard rocks). Thereby, we can obtain a more accurate value of UCS.

4) The number of tested specimens satisfied the accuracy requirements based on the coefficient of variation. The IPLS was strongly correlated with the UCS. Therefore, the relationships between IPLS and UCS established in this study were highly precise.

5) The IPLS and NP tests were convenient and effective because they could be performed promptly using onsite and laboratory testing equipment for various shaped small rock specimens taken from outcrops or floats.

\section{References}

[1] D’Andrea, D.V., Fischer, R.L. and Fogelson, D.E. (1964) Prediction of Compressive Strength from Other Rock Properties. Colorado School of Mines Quarterly, 59, 623-640.

[2] Broch, E. and Franklin, J.A. (1972) The Point-Load Strength Test. International Journal of Rock Mechanics and Mining Sciences, 9, 669-697.

https://doi.org/10.1016/0148-9062(72)90030-7 
[3] Bieniawski, Z.T. (1974) Estimating the Strength of Rock Materials. Journal of the Southern African Institute of Mining and Metallurgy, 74, 312-320. https://doi.org/10.1016/0148-9062(74)91782-3

[4] Bieniawski, Z.T. (1975) Point Load Test in Geotechnical Practice. Engineering Geology, 9, 1-11. https://doi.org/10.1016/0013-7952(75)90024-1

[5] Brook, N. (1977) The Use of Irregular Specimens for Rock Strength Test. International Journal of Rock Mechanics and Mining Sciences and Geomechanics Abstracts, 14, 193-202. https://doi.org/10.1016/0148-9062(77)90948-2

[6] Brook, N. (1980) Size Correction for Point Load Testing. International Journal of Rock Mechanics and Mining Sciences and Geomechanics, 17, 231-235.

https://doi.org/10.1016/0148-9062(80)91090-6

[7] Hassani, F.P., Scoble, M.J. and Whittaker, B.N. (1980) Application of the Point Load Index Test to Strength Determination of Rock and Proposals for a New Size-Correction Chart. In: Summers, D.A., Ed., Proceedings of the 21 st US Symposium on Rock Mechanics, 543-564.

[8] ISRM Commission on Testing Methods, Working Group on Revision of the Point Load Test Method (1985) Suggested Method for Determining Point Load Strength (Coordinator Franklin, J.A.). International Journal of Rock Mechanics and Mining Sciences and Geomechanics Abstracts, 22, 51-60. https://doi.org/10.1016/0148-9062(85)92327-7

[9] Brook, N. (1985) The Equivalent Core Diameter Method of Size and Shape Correction in Point Load Testing. International Journal of Rock Mechanics and Mining Sciences and Geomechanics Abstracts, 22, 61-70. https://doi.org/10.1016/0148-9062(85)92328-9

[10] Hikita, S. and Kikuchi, M. (1988) A Consideration on the Utility of the Point Load Test. A Monthly Newsletter of Civil Engineering of Institute, 423, 30-41. (In Japanese)

[11] Kahraman, S. (2001) Evaluation of Simple Methods for Assessing the Uniaxial Compressive Strength of Rock. International Journal of Rock Mechanics and Mining Sciences, 38, 981-994. https://doi.org/10.1016/0148-9062(85)92328-9

[12] Tsiambaos, G. and Sabatakakis, N. (2004) Considerations on Strength of Intact Sedimentary Rock. Engineering Geology, 72, 261-273. https://doi.org/10.1016/j.enggeo.2003.10.001

[13] Basu, A. and Aydin, A. (2006) Predicting Uniaxial Compressive Strength by Point Load Test: Significance of Cone Penetration. Rock Mechanics and Rock Engineering, 39, 483-490. https://doi.org/10.1007/s00603-006-0082-y

[14] Agustawijaya, D.S. (2007) The Uniaxial Compressive Strength of Soft Rock. Civil engineering Dimension, 9, 9-14.

[15] Kohno, M. and Maeda, H. (2012) Relationship between Point Load Strength Index and Uniaxial Compressive Strength of Hydrothermally Altered Soft Rocks. International Journal of Rock Mechanics and Mining Sciences, 50, 147-157. https://doi.org/10.1016/j.ijrmms.2012.01.011

[16] Wong, R.H.C., Chau, K.T., Yin, J.-H., Lai, D.T.W. and Zhao, G.-S. (2017) Uniaxial Compressive Strength and Point Load Index of Volcanicirregular Lumps. International Journal of Rock Mechanics and Mining Sciences, 93, 307-315. https://doi.org/10.1016/j.ijrmms.2017.02.010

[17] Palk, Y.H., Obara, Y. and Kang, S.S. (2011) Estimation of Uniaxial Compressive Strength of Weak Rocks using Needle Penetrometer. In: Qian, Q. and Zhou, Y., Eds., Proceedings of the 12 th ISRM International Congress on Rock Mechanics, 
795-798.

[18] Ngan-Tillard, D.J.M., Verwaal, W., Mulder, A., Engin, H.K. and Ulusay, R. (2011) Application of the Needle Penetration Test to a Calcarenite, Maastricht, the Netherlands. Engineering Geology, 123, 214-224.

https://doi.org/10.1016/j.enggeo.2011.08.004

[19] Ngan-Tillard, D.J.M., Engin, H.K., Verwaal, W., Mulder, A., Ulusay, R. and Erguler, Z.A. (2012) Evaluation of Micro-Structural Damage Caused by Needle Penetration Testing. Bulletin of Engineering Geology and the Environment, 71, 487-498. https://doi.org/10.1007/s10064-012-0430-y

[20] Ulusay, R. and Erguler, Z.A. (2012) Needle Penetration Test: Evaluation of Its Performance and Possible Uses in Predicting Strength of Weak and Soft Rocks. Engineering Geology, 149-150, 47-56. https://doi.org/10.1016/j.enggeo.2012.08.007

[21] Azadan, P. and Ahangari, K. (2014) Evaluation of the New Dynamic Needle Penetrometer in Estimating Uniaxial Compressive Strength of Weak Rocks. Arabian Journal of Geosciences, 7, 3205-3216. https://doi.org/10.1007/s12517-013-0921-6

[22] Ulusay, R., Aydan, Ö.,Erguler, Z.A., Ngan-Tillard, D.J.M., Seiki, T., Verwaal, W., Sasaki, Y. and Sato, A. (2014) ISRM Suggested Method for the Needle Penetration Test. Rock Mechanics and Rock Engineering, 47, 1073-1085. https://doi.org/10.1007/s00603-013-0534-0

[23] Kahraman, S., Aloglu, A.S., Aydin, B. and Saygin, E. (2017) The Needle Penetration Test for Predicting Coal Strength. Journal of the Southern African Institute of Mining and Metallurgy, 117, 587-591. https://doi.org/10.17159/2411-9717/2017/v117n6a9

[24] Okada, S., Izumiya, Y., Iizuka, Y. and Horiuchi, S. (1985) The Estimation of Soft Rock Strength around a Tunnel by Needle Penetration Test. Journal of the Japanese Society of Soil Mechanics and Foundation Engineering, 33, 35-38. (In Japanese)

[25] Kohno, M., Maeda, H., Kage, I., Kotake, J. and Nii, M. (2010) Method of Axial Point Load Strength Test for Smectite-Bearing Rocks. Japan Society of Civil Engineers Journal of Geotechnical and Geoenvironmental Engineering, 66, 859-868. (In Japanese) 